Access to Justice in Eastern Europe,

Issue 2/3 (7) 2020

ISSN 2663-0575 (Print)

ISSN 2663-0583 (Online)

http://ajee-journal.com

10.33327/AJEE-18-3.2-3

O Kaplina, S Sharenko 'Access to Justice

in Ukrainian Criminal Proceedings

During the COVID-19 Outbreak' (2020)

$2 / 3(7)$

Access to Justice in Eastern Europe 115-133.

10.33327/AJEE-18-3.2-3-a000029

\title{
ACCESS TO JUSTICE \\ IN UKRAINIAN CRIMINAL PROCEEDINGS DURING THE COVID-19 OUTBREAK
}

\author{
Kaplina Oksana \\ Dr. Sc. (Law), Prof.,Head of Department \\ of Criminal Procedure, \\ Yaroslav Mudryi National Law University, Ukraine
}

\section{Sharenko Svitlana \\ PhD (Law), Chairman of the Kyiv District Court, Ukraine}

Summary: - 1. Introduction. - 2. The Right to a Fair Trial Under a Pandemic Condition: Are There Reasons to Derogate from the Fundamental Provision of the European Convention? - 3. Main Challenges of Criminal Judiciary Under Conditions of a COVID-19 Pandemic in Ukraine and Ways to Solve Them. - 3.1. Publicity under Conditions of Quarantine. - 3.2. Access to Videoconferencing as a Guarantee of the

Received: 13.07.2020. Revised: 03.08.2020. Approved: 14.08.2020

(C) 2020 Access to Justice in Eastern Europe, Oksana Kaplina and Svitlana Sharenko.

This work is licensed under a CC BY NC ND 4.0 license.

This is an Open Access publication distributed under the terms of the Creative Commons Attribution 4.0 International License which permits to copy and distribute the material in any medium or format in unadapted form only, for noncommercial purposes only, and only as long as attribution is given to the creator. 
Right to be Heard in Court. - 3.3. Observance of Guarantees of the Victim's Rights in the Conditions of a Pandemic. - 3.4. Reasonable Time Limits for Consideration of Criminal Cases in a Pandemic. - 3.5. Peculiarities of Judicial Control Proceedings in a Pandemic. - 4. Conclusions.

This article examines relevant issues of criminal proceedings in the context of the COVID-19 pandemic in Ukraine. In the wake of the COVID-19 pandemic, many governments have focused their efforts on protecting democratic values and ensuring not only the rights and legitimate interests of their people, but also their lives and health. At the same time, the pandemic has affected not only the economies of countries, but also their democratic development and fundamental rights, which have always been a priority of any democratic society. Courts and law enforcement authorities have faced challenges that have been and still are adequately addressed in order to ensure that the rights and legitimate interests of those seeking judicial protection are respected.

Each state independently assessed the degree of risks and the extent of permissible restrictions on the rights and freedoms of persons involved in the proceedings, so the present study analyses the different approaches that have been applied. At the same time, documents of the Council of Europe for the Efficiency of Justice (CEPEJ) have gained high importance, because they, among others, have developed tools for Council of Europe member states to address the problems of ensuring access to justice in the pandemic. The generalization and widespread discussion of such experiences is important, because it will be useful for states to further improve existing legislation, taking into account best practices.

Based on a study of changes introduced in the Ukrainian legislation to prevent the spread of the coronavirus disease, conclusions are proposed about the nature and extent of the restrictions, as well as the principles on which they should be based and the guarantees to be provided. Recommendations that will contribute to improving the regulation of access to justice in criminal matters in a pandemic are also proposed.

Key words: justice in the context of the COVID-19 pandemic; access to justice in the context of the COVID-19 pandemic; judicial control over the protection of rights, freedoms and legitimate interests of persons in criminal proceedings; the investigating judge; reasonable terms of criminal proceedings; publicity and openness of court proceedings; trial by videoconference.

\section{INTRODUCTION}

The coronavirus epidemic has had a devastating effect on humanity, regardless of geography, economic status, maturity of society or any other components. The pandemic has become a serious test for the legal systems of almost all states and civilizations. At the beginning, it was impossible to predict the full range of consequences this brought, but realizing those now, it is worth drawing conclusions for the future.

Ensuring human health during the coronavirus pandemic has become one of the top topics worldwide. The most problematic issues were the provision of adequate medical care, the development of treatment protocols and the creation of a vaccine 
against a disease that has become a threat to humanity. Representatives of the medical professions were at the forefront of the fight against this dangerous disease. Obviously, we should pay tribute to medical providers, which were the first to defend humanity.

At the same time, the coronavirus pandemic has affected the democratic development of countries, the rule of law and the protection of human rights. Courts and law enforcement systems have faced significant challenges, which need to be adequately addressed to ensure that the rights and legitimate interests of those in need of judicial protection are respected.

This article addresses the challenges facing the society of democracies in respect to the fundamental rights of access to justice in criminal matters, as guaranteed by the Universal Declaration of Human Rights ${ }^{1}$ and the European Convention (Convention for the Protection of Human Rights and Fundamental Freedoms, hereinafter - Convention), ${ }^{2}$ as well as ways to overcome them as illustrated by the example of Ukraine.

Restrictive measures in Ukraine were introduced by the Resolution of the Cabinet of Ministers of Ukraine of 11 March 2020 № 211 'On Prevention of the Spread of Acute Respiratory Disease COVID-19 Caused by Coronavirus SARS-CoV-2.'

The first version of this resolution provided, among others, for a ban on holding mass events with more than 200 participants, in addition to the measures necessary to ensure the work of public authorities and local governments. In addition, the Resolution has been repeatedly amended and supplemented, taking into account the epidemiological situation in the country.

However, in accordance with the Constitution, ${ }^{4}$ it is the laws of Ukraine that determine the judicial system, judicial proceedings, the status of judges; the principles of forensic examination; the organization and activity of the prosecutor's office, notary, pre-trial investigation bodies, bodies and institutions of execution of punishments; the order of court decisions execution; the principles of the organization of the bar (paragraph 14 of Art. 92).

Thus, despite the introduction of quarantine measures, the procedural order of criminal proceedings was not changed and the courts had to overcome gaps in legislation by balancing between the provisions of the Resolution of the Cabinet of Ministers of Ukraine and the requirements of criminal procedure legislation.

Only on 30 March 2020, the Law of Ukraine 'On Amendments to Certain Legislative Acts of Ukraine Aimed at Providing Additional Social and Economic Guarantees in

1 United Nations, Universal Declaration of Human Rights (10 December 1948). <https://www.un.org/en/ universal-declaration-human-rights/> accessed 03 August 2020.

2 Council of Europe, European Convention for the Protection of Human Rights and Fundamental Freedoms [1950] ETS 5 <https://www.echr.coe.int/Documents/Convention_ENG.pdf> accessed 03 August 2020.

3 The Resolution of the Cabinet of Ministers of Ukraine № 211 of 11 March 2020 'On Prevention of the Spread of Acute Respiratory Disease COVID-19 Caused by Coronavirus SARS-CoV-2’ Official Gazette of Ukraine 23/296 Art 896.

4 Constitution of Ukraine: Law of Ukraine of 28 June 1996 № 27-IX. <https://zakon.rada.gov.ua/laws/ show/254к/96-вр\#Text> accessed 03 August 2020. 
Connection with the Spread of Coronavirus Disease (COVID-19)'5 was adopted (with subsequent amendments on 24 June 2020) (hereinafter - Law № 540-IX).

By this Law of Ukraine, the legislator established certain restrictions concerning the attendance in the courtroom during the trial and also tried to regulate certain features of judicial control over the observance of the rights, freedoms and interests of persons in criminal proceedings.

Amendments to the legislation on the procedural time limits in commercial, civil and administrative proceedings during quarantine were introduced by the Law of Ukraine only on 18 June $2020 .{ }^{6}$ However, the legislator ignored the criminal procedure legislation. Thus, judges and investigating judges had to overcome the problems and the lack of criminal procedural legislation in the absence of proper regulation.

It is clear that during a pandemic, the introduction of certain restrictions is a necessary measure to preserve the health of the population, but at the same time, emergency measures must be based on the principles of rule of law, legality, legal certainty and proportionality.

\section{THE RIGHT TO A FAIR TRIAL UNDER A PANDEMIC CONDITION: ARE THERE REASONS TO DEROGATE FROM THE FUNDAMENTAL PROVISION OF THE EUROPEAN CONVENTION?}

The governments of different states have responded differently to the challenges facing their justice systems, but they have acted similarly in the means they have chosen to prevent the spread of the disease and ensure access to justice for citizens.

Regional human rights systems have also responded quickly to the challenges of the times. In particular, the Council of Europe for the Efficiency of Justice (CEPEJ) has adopted the CEPEJ Declaration 'Lessons Learned and Challenges Faced by The Judiciary During and After the COVID-19 Pandemic'. The declaration contains principles that CEPEJ would like to remind the member states of the Council of Europe to uphold.? In turn, on 7 April 2020 the Council of Europe adopted a toolkit for member states 'Respecting Democracy, Rule of Law and Human Rights in the Framework of the COVID-19 Sanitary Crisis. ${ }^{8}$

It would be appropriate to draw attention to one point, which was emphasized in the Toolkit for the member states of the Council of Europe: 'Effective enjoyment of all

$5 \quad$ The Law of Ukraine 'On Amendments to Certain Legislative Acts of Ukraine Aimed at Providing Additional Social and Economic Guarantees in Connection with the Spread of Coronavirus Disease (COVID-19)' [2020] Vidomosti of the Verkhovna Rada 18/123 < https://zakon.rada.gov.ua/laws/ show/540-IX\#Text> accessed 03 August 2020.

6 The Law of Ukraine 'On Amendments to Certain Legislative Acts of Ukraine Concerning the Procedural Terms during Quarantine Established by the Cabinet of Ministers of Ukraine for the Prevention of the Spread of Coronavirus Disease (COVID-19)' Official Gazette [2020] 58/1835 Art 13.

7 CEPEJ, 'Lessons Learnt and Challenges Faced by the Judiciary during and after the COVID-19 Pandemic' (10 June 2020) CEPEJ 8rev <https://rm.coe.int/declaration-en/16809eale2> accessed 03 August 2020.

8 Council of Europe, 'Respecting democracy, rule of law and human rights in the framework of the COVID-19 sanitary crisis: A toolkit for member states' (7 April 2020) <https://www.coe.int/en/web/ congress/covid-19-toolkits> accessed 03 August 2020. 
these rights and freedoms guaranteed by Art.s 8, 9, 10 and 11 of the Convention is a benchmark of modern democratic societies. Restrictions on them are only permissible, if they are established by law and proportionate to the legitimate aim pursued, including the protection of health. It is for the authorities to ensure that any such restriction, whether or not it is based on a temporary derogation, is clearly established by law, in compliance with relevant constitutional guarantees and proportionate to the aim it pursues' (para 3.3). ${ }^{9}$

According to Art. 15 of the Convention, ${ }^{10}$ a member state may take measures derogating from its obligations under this Convention, in the event of war or other public danger threatening the life of the nation. Since the beginning of the pandemic declared by the World Health Organization nine states, declaring a state of emergency on their territory, have exercised this right. These include Albania, Armenia, Georgia, Estonia, Latvia, Moldova, Romania, San Marino and Serbia. ${ }^{11}$

In particular, Estonia, having declared a state of emergency in the country on 12 March 2020, on March 20 made a statement to the Council of Europe on the derogation from obligations in accordance with Art. 15 of the Convention. ${ }^{12}$ The Estonian Government stated that the State had departed from its obligations under Art. 5, 6, 8 and 11 of the Convention, Art. 1, 2 of the First Protocol, Art. 2 of the Fourth Protocol to the Convention.

The Annex to the Note verbale JJ9017C of the Permanent Representation Estonia to the Council of Europe states that in case of prosecutors, the judge can require that they attend the hearing through a video bridge (clause 15 Appendix 3); where possible, the litigation is handled in writing. Written proceedings have to be carried out through the information system of courts and by means of a digital court file application (clause 9 Appendix 3); the courts prefer the public e-File and email when choosing the method of service of procedural documents (clause 18 Appendix 3). During emergency situation, the hearings that are absolutely necessary for the performance of unforeseen or urgent service duties will be held by technical means of communication. The Annex to this paragraph provides a list of urgent cases, including taking into custody or deciding whether it should be continued (section 130, clause 262 4, section 275, section 3951, section 429, section 447 of the Code of Criminal Procedure).

On 21 March 2020, the President of Georgia declared a state of emergency, and on 23 March 2020, Georgia notified the Council of Europe of the derogation from obligations in accordance with Art. 15 of the Convention. Among the articles identified by the President, were Art. 5, 8, 11 of the Convention, Art. 1, 2 of the First Protocol and Art. 2 of the Fourth Protocol.

\footnotetext{
$9 \quad$ Council of Europe (n 8).

10 Council of Europe, European Convention for the Protection of Human Rights and Fundamental Freedoms [1950] ETS 5 <https://www.echr.coe.int/Documents/Convention_ENG.pdf> accessed 03 August 2020.

11 Council of Europe, 'Notifications under Article 15 of the Convention in the context of the COVID-19 pandemic' <https://www.coe.int/en/web/conventions/full-list/-/conventions/webContent/62111354> accessed 03 August 2020.

12 Council of Europe (n 2).
} 
The following measures have been introduced in criminal proceedings: court sessions under the Criminal Procedural legislation of Georgia may be held remotely using electronic means. In such cases, the parties to the case have no right to deny the conduct of remote sessions while requesting direct participation in it. ${ }^{13}$

On 16 March 2020 the President of Romania declared a state of emergency on the territory of the state and issued Decree № $195^{14}$ which establishes emergency measures aimed at combating the spread of coronavirus on the territory of the state. The Decree warned that these measures could lead to restrictions of certain constitutional rights and freedoms of a human and a citizen, as reported by the Romanian Representation in the Council of Europe on 17 March 2020. The Romanian authorities did not name specific articles of the Convention requirements which can be indented.

According to the Decree of the President of Romania № 195, court hearings pending before the courts, taking into account the previous ones, are automatically suspended during the state of emergency. Only the following cases are subject to consideration:

'1) cases where preventive or protective measures for victims and witnesses have been taken or proposed, those regarding the provisional application of safety measures having a medical nature, those involving minors as victims; 2) acts and measures of criminal prosecution whose delay would endanger the collection of evidence or the apprehending of the suspect or of the defendant, as well as those regarding the early hearing; 3 ) cases whose emergency is justified by the purpose of establishing the national state of emergency, other urgent cases determined by the prosecutor supervising or carrying out the criminal prosecution etc. ${ }^{15}$

In 10 days after the termination of the state of emergency, the judge or the court will take measures to set time limits for the judicial procedure and to carry out the procedural acts.

In addition, the Decree of the President of Romania touched upon other important provisions, in particular, for criminal cases, the agreement to circulate procedural documents through electronic mail is presumed and the judicial bodies shall request via phone, as needed, on an emergency basis, the electronic addresses to communicate those respective documents (para 4 Art. 43). The time limits to communicate decisions and to submit and solve complaints other than those mentioned in paragraph 1 are interrupted, whereas new time limits of similar duration will run following the termination of the state of emergency. The terms for lodging appeals in criminal cases, with the exception of those tried under the present Decree, are interrupted, whereas a new time limit of similar duration will run from the date of terminating the state of emergency. The cases tried based on the present Decree are an exception (para 5 Art. 43). The right to be heard of persons deprived of their liberty shall be ensured via videoconference at the detention place or in spaces which are appropriate from the health point of view,

13 Note Verbale of the Permanent Representation of Georgia in the Council of Europe with Annex No JJ9018C of 23 March $2020<$ https://rm.coe.int/16809cff20> accessed 03 August 2020.

14 The President of Romania Decree 'On the establishment of the state of emergency in the territory of Romania' of 16 March 2020 Official Gazette of Romania, Part I, No 212 <https://rm.coe.int/16809e375d > accessed 03 August 2020. 
without being necessary to obtain the agreement of person deprived of liberty (para 6 Art. 43). The organization of public auction for the realization of assets preserved during criminal proceedings is suspended by law (para 7 Art. 43). During the state of emergency, in cases where no criminal investigations are performed or the criminal procedure is being suspended in accordance with the current Decree, the prescription of criminal liability is suspended (para 8 Art. 43). ${ }^{16}$

Ukraine has not declared derogation from the Convention, and therefore, the antiepidemiological measures introduced in criminal proceedings should be based on the inadmissibility of restrictions on fundamental human rights guaranteed by the Convention.

The vast majority of the changes introduced by the Ukrainian legislature were established by law, pursued a legitimate aim, were proportionate and necessary in a democratic society. At the same time, the analysis of the main challenges that have arisen in criminal proceedings in a pandemic show that some of the decisions taken need to be improved.

\section{MAIN CHALLENGES OF CRIMINAL JUDICIARY UNDER CONDITIONS OF A COVID-19 PANDEMIC IN UKRAINE AND WAYS TO SOLVE THEM}

During the introduction of quarantine measures, the main problems facing domestic courts were the problems of ensuring the implementation of the requirements of Art. 6 of the Convention and the relevant provisions of criminal procedural law, which are implemented in national law, while taking into account international legal standards for the administration of justice and respect for human rights that exist in the world.

In particular, the right to a fair trial contains the following components: the access to justice; the consideration of the case by a court established by law; the independence and impartiality of the court; a fair trial; the publicity of the trial; legal certainty; the execution of the final court decision; reasonable terms.

The fairness of the trial, in accordance with the Convention, determines the right to be present at the hearing; the right to effective participation in court proceedings; the equality of procedural opportunities of the parties; the adversarialism of the parties; the admissibility of only legally obtained evidence; the immediacy of the study of evidence; the freedom from self-accusation.

\subsection{Publicity under Conditions of Quarantine}

The first real problem faced by domestic courts was the impossibility of ensuring the transparency of criminal proceedings.

According to Art. 27 of the CPC 'Publicity and Openness of Court Proceedings and Full Recording of Court Hearings and Procedural Actions by Technical Means, ${ }^{17}$ criminal

16 Note Verbale of the Permanent Representation of Romania in the Council of Europe with Annex No JJ9014C of 18 March 2020 <https://rm.coe.int/16809cee30> accessed 03 August 2020.

17 Criminal Procedure Code of Ukraine: Law of Ukraine of 13 April 2012 № 817-IX <https://zakon.rada. gov.ua/laws/show/4651-17\#Text> accessed 03 August 2020. 
proceedings in courts of all instances are carried out openly. The normative basis of this principle is the provision of paragraph 6 of Part 2 of Art. 129 of the Constitution of Ukraine, ${ }^{18}$ Art. 11 of the Law of Ukraine 'On the Judiciary and the Status of Judges, ${ }^{19}$ international legal acts, in particular, Art. 10 of the Universal Declaration of Human Rights, ${ }^{20}$ Part 1 of Art. 6 of the Convention on Human Rights, part 1 of Art. 14 of the International Covenant on Civil and Political Rights. ${ }^{21}$

The essence of this principle in criminal proceedings is that it is:

1) a guarantee of the transparency of the judiciary, which significantly contributes to the formation of public trust;

2) a means of public control over the administration of justice;

3) a means of exercising educational influence on persons who were present in the courtroom, as well as on the members of society as a whole, promoting the development of legal culture and legal awareness of citizens;

4) one of the conditions of a fair trial.

Law № 540-IX 22 amended the CPC of Ukraine, which gave the judge and the investigating judge the right to decide to restrict access of persons, who are not participants in the trial to the court session if participation in the court session will endanger the life or health of a person. This is valid during the quarantine established by the Cabinet of Ministers of Ukraine in accordance with the Law of Ukraine 'On Protection of the Population from Infectious Diseases', We would like to draw attention to the fact that the legislator did not limit the validity of the principle of 'publicity and openness of court proceedings' to such innovations,

but only proposed certain restrictions related to discretion, timeliness, selectivity and purposefulness.

In particular, it is about the following powers:

1) make a decision to restrict the access of persons to a court hearing, which is at the discretion of the judge and/or the investigating judge;

2) a judge and/or an investigating judge may only restrict the access of persons to the courtroom, but not completely prohibit it;

3) the introduced restrictions may only be applied for the period of quarantine established by the Cabinet of Ministers of Ukraine;

18 Constitution (n 4$)$.

19 The Law of Ukraine 'On the Judiciary and Status of Judges' [2016] Vidomosti of the Verkhovna Rada 31/545 < https://zakon.rada.gov.ua/laws/show/1402-19\#Text> accessed 03 August 2020.

20 United Nations, Universal Declaration of Human Rights (10 December 1948).

21 United Nations, International Covenant on Civil and Political Rights (16 December 1966) <https://www. ohchr.org/en/professionalinterest/pages/ccpr.aspx> accessed 03 August 2020.

22 The Law of Ukraine 'On Amendments to Certain Legislative Acts of Ukraine Aimed at Providing Additional Social and Economic Guarantees in Connection with the Spread of Coronavirus Disease (COVID-19)' [2020] Vidomosti of the Verkhovna Rada 18/123 < https://zakon.rada.gov.ua/laws/ show/540-IX\#Text> accessed 03 August 2020. 
4) restriction of access applies only to persons who are not participants in the proceedings;

5) restrictions on access to a court hearing may be introduced only in the event of a threat to the life or health of a person (Law № 540-IX).

As can be concluded from this, the purpose of this decision of the court or investigating judge is multivariate. It can be considered in broad and narrow meanings. In particular, in the narrow sense, it restricts the access of persons who are not participants in the trial to the hearing, and in the broad sense, it ensures the life and health of the participants in the trial and prevents the spread of coronavirus disease in Ukraine (COVID-19).

The legal grounds for the decision to restrict the access of persons to the trial are the decision of the investigating judge, which must be legal and reasonable. The factual grounds for such a decision are the possibility of a threat to life or health. So, the legislator thus created an evaluative concept, which is interpreted differently by practitioners, but the investigating judge or the judge must properly justify the decision to restrict access to the trial.

It is very difficult to decide whether a threat to a person's life or health is created during a court hearing, as there is legal uncertainty regarding the person referred to in the amendments to Art. 27 of the CPC. In our opinion, this article should be interpreted broadly and access of persons to the court hearing should be restricted, if there is a threat to the life and health of all present in the courtroom, namely the investigating judge, other court members, participants in the proceedings, which are defined in paragraph 26 of Art. 3 of the CPC. ${ }^{23}$

Also, when interpreting this provision, it should be assumed that the main task of the court decision in restricting access to the courtroom should be preventing harmful consequences that may occur due to the presence of persons who are not participants in the proceedings.

In addition, the difficulty of interpreting this evaluation concept is that often when deciding on the prevention of harmful effects, one of the conditions for their use is the presence of real danger. But to establish the presence of real danger in a pandemic is very difficult as the 'enemy' is invisible.

Of course, there is a real danger for litigants when a temperature screening, which was mandatory in accordance with anti-epidemic measures, identifies a person or persons who have a fever. However, it is known that fever can accompany a number of other diseases. Therefore, the judge who must decide to restrict the access of persons to the trial must proceed from the following reasoning.

In itself, the introduction of quarantine measures in the state indicates the prevalence of the disease to an indefinite number of people, and many of the patients may be so-

23 In particular, participants in the proceedings: the parties to the criminal proceedings, the victim, their representative and legal representative, civil plaintiff, their representative and legal representative, civil defendant and their representative, a representative of the legal entity under trial, a representative of the probation body, a third party, in respect of whose property the issue of arrest is resolved, as well as other persons at the request or complaint of which in cases provided by the CPC, court proceedings are conducted. 
called 'asymptomatic carriers', which is a specificity of the COVID-19 disease. In our opinion, only the existence of patients with a dangerous disease in a certain area, which determined the introduction of large-scale quarantine measures, indicates a threat to the health and life of the court, the investigating judge and persons involved in the proceedings.

The problem under consideration will not be solved by the requirement to provide a certificate of the absence of the virus in the body, PCR tests for COVID-19, because the disease spreads very quickly, and the incubation period lasts up to two weeks.

The protection of the life and health of citizens of the country is a legitimate aim, which stipulates the right of a judge and an investigating judge to restrict the presence in the courtroom of persons who are not its participants.

Therefore, in our opinion, the grounds for deciding to restrict the access to the trial of persons who are not participants in the trial may be:

1) introduction by law of quarantine measures in the state (on a certain territory, locality, in a certain place);

2) a threat to life and health, which objectively exists during the spread of the disease that caused the introduction of quarantine measures on the territory of the state;

3) the opinion of the investigating judge, the court of probable judgment, that there is a threat to life and health of the court and the participants in the proceedings, which arises on the basis of internal conviction, formed on the basis of the general situation in the state (in a certain territory, area, place);

4) the possibility of adverse effects is due to objective circumstances, the danger of the disease and the specificity of its spread;

5) danger can jeopardize not only the health but also the life of persons involved in criminal proceedings.

Taking into account the experience of other states ${ }^{24}$ in our opinion, in order to comply both with the requirements of the Convention on publicity of court proceedings and Ukrainian legislation regarding the implementation of the principle of publicity of court proceedings, it is advisable to cover the most 'high-profile' lawsuits in the media; providing online broadcasts of court hearings; audio broadcast of court hearings, etc.

24 See more about Great Britain's experience in: 'Coronavirus Act 2020' (Chapter 7) <https://www. legislation.gov.uk/ukpga/2020/7/pdfs/ukpga_20200007_en.pdf> accessed 03 August 2020, 'Supporting the justice system from home' <https://www.judiciary.uk/announcements/supporting-the-justicesystem-from-home/> accessed 03 August 2020, and 'Courts and tribunals data on audio and video technology use during coronavirus outbreak' (14 April 2020) <https:/www.gov.uk/guidance/courtsand-tribunals-data-on-audio-and-video-technology-use-during-coronavirus-outbreak> accessed 03 August 2020. See also: 'COVID-19 Global: Arbitration and court impacts' (1 May 2020) <https://www. clydeco.com/en/insights/2020/05/COVID-19-impact-on-courts-and-arbitration> accessed 03 August 2020; on consideration by the US Supreme Court by videoconference with open public access to the broadcast, see 'Virus Pushes a Staid Supreme Court Into Revolutionary Changes' The New York Times, 3 May $2020<$ https://www.nytimes.com/2020/05/03/us/politics/supreme-court-coronavirus.html> accessed 03 August 2020. 
Such measures will promote the implementation of the principle of publicity of court proceedings and respect the rights of persons arising from the legal content of this principle.

\subsection{Access to Videoconferencing as a Guarantee of the Right to be Heard in Court}

The termination, in accordance with the Resolution of the Cabinet of Ministers № $211,{ }^{25}$ of regular and irregular carriage of passengers by road in suburban, intercity, intraregional and interregional communication (except for passenger cars), rail transport, international air traffic have led to significant complications or have made the participation in the hearing of their case in court for parties impossible.

The State Judicial Administration of Ukraine, taking into account international experience, pursuant to Law № 540-IX and the Law of Ukraine 'On the Judiciary and Status of Judges', issued an order approving the Procedure for working with videoconferencing during court, administrative, civil and economic proceedings with the participation of the parties outside the court building. ${ }^{26}$

However, as you can see, this act was aimed at normalizing the procedure for videoconferencing during court hearings in administrative, civil and commercial proceedings, but at the same time ignored the criminal process.

Probably, such a situation has developed due to the fact that the procedure of videoconferencing during court proceedings is provided by the CPC of Ukraine in Art. 336 and was had been widely used even before the introduction of antiepidemiological measures.

At the same time, the Verkhovna Rada of Ukraine adopted the Law amending the CPC of Ukraine on the peculiarities of judicial control over the observance of rights, freedoms and interests of persons in criminal proceedings and consideration of certain issues during court proceedings for the period of quarantine established by the Cabinet of Ministers with the aim of prevention of the spread of coronavirus disease (COVID-19). ${ }^{27}$

This Law, in particular, stipulates that consideration of issues related to the powers of an investigating judge or court (except for consideration of a request to choose a measure of restraint in the form of detention) can be conducted by videoconference with prior notification of the parties to the criminal proceedings. This can be done by the decision of an investigating judge or court, taken on their own initiative or at the request of a party to the criminal proceedings. The investigating judge or court have no right to decide to hold

25 The Resolution of the Cabinet of Ministers № 211 [2020] Official Gazette of Ukraine 23/296 Art 896.

26 Order of the State Judicial Administration of Ukraine of 8 April 2020 № 169 'On approval of the Procedure for working with technical means of videoconferencing during a court hearing in administrative, civil and commercial proceedings with the participation of the parties outside the court' $<$ https://drive. google.com/file/d/1PdQ6oIR-C5HnIJYSYox95PwXdLvk9ojC/view> accessed 03 August 2020.

27 The Law of Ukraine 'On Amendments to Paragraph 20-5 of Section XI 'Transitional Provisions' of the Criminal Procedure Code of Ukraine on the peculiarities of judicial control over the rights, freedoms and interests of persons in criminal proceedings and consideration of certain issues during court proceedings for the period of quarantine The Cabinet of Ministers of Ukraine in order to prevent the spread of coronavirus disease (COVID-19)' [2020] Bulletin of the Verkhovna Rada of Ukraine 19 Art 129. 
a court hearing to consider the request for the extension of detention in a videoconference, in which the suspect (accused) is outside the courtroom, if he objects to this.

Conducting a court hearing by videoconference, including during court proceedings, shall be done in compliance with the rules provided for in Part 3-9 of Art. 336 of the CPC of Ukraine (paragraph 20-5 of Section XI 'Transitional Provisions' of the CPC of Ukraine).

The legislator has established that only a request for a measure of restraint in the form of detention cannot be considered by videoconference. This approach is quite justified given that detention significantly restricts the constitutional human right to liberty and security of person guaranteed by Art. 29 of the Constitution of Ukraine, Art. 5 of the Convention.

While not absolute, this right may be subject to restrictions, but its application must respect the guarantees that the interference with human rights is lawful. At the same time, the possibility of holding a court hearing to consider the request for extension of detention in a videoconference, in which the suspect (accused) is outside the courtroom, depends on his consent.

In our opinion, in conditions when Ukraine did not use the right provided by Art. 15 of the Convention, according to which a State may decide to derogate from its obligations under the Convention, the provision on the possibility of videoconferencing to extend a detention may lead to a formal approach, essentially a quasi-automatic extension of the detention period.

In its judgments (Shishkov vs Bulgaria, ${ }^{28}$ Tase vs Romania ${ }^{29}$ ) the ECHR stated that the justification for any period of detention, whatever it may be, must be convincingly provided by the State and that a quasi-automatic extension of such a period runs counter to the guarantees established in paragraph 3 of Art. 5 of the Convention.

Of course, it can be argued that under current criminal procedural law, a suspect or accused must consent to a request for continued detention by videoconference. However, there is a question of voluntariness of such consent. This approach appears to be discriminatory compared to the procedure that exists for the choice of a measure of restraint, when the consideration of this issue by the investigating judge by videoconference is inadmissible.

In addition, case law shows that judges do not always check the voluntariness of consent, which should be mandatory. ${ }^{30}$ Forcing a suspect or accused person to an offer of a trial by videoconference can significantly affect the rights of those subject to pre-trial detention.

\subsection{Observance of Guarantees of the Victim's Rights in the Conditions of a Pandemic}

Attention should also be paid to the observance of the procedural rights of a victim. If we refer to the international standards of the victim's participation in court proceedings

28 Shishkov v. Bulgaria (App no 38822/97) ECHR 9 January 2003 <http://hudoc.echr.coe.int/ eng? $\mathrm{i}=001-60879>$ accessed 03 August 2020.

29 Tase v. Romania (App no 29761/02) ECHR 10 June 2008 <http://hudoc.echr.coe.int/eng?i=001-86861> accessed 03 August 2020.

30 Case № 212/8969/18 (Zhovtnevy District Court of the city of Kryvyi Rih, Dnipropetrovsk Oblast 4 August 2020). < http://reyestr.court.gov.ua/Review/90746091 > accessed 03 August 2020. 
regarding the choice or change of a measure of restraint for a suspect or accused, we can conclude that international acts are based on the need to take into account the victim's opinion on the choice of a measure of restraint.

The Declaration of Fundamental Principles of Justice for Victims of Crime and Abuse of Power enshrines the obligation of States to promote that judicial and administrative procedures are more responsive to the needs of victims of crime. This is done by ensuring that their views are expressed and considered at certain stages of the trial in cases where their personal interests are involved, without prejudice to the accused and in accordance with the national criminal justice system. ${ }^{31}$

The ECtHR in its decision in the case of Batsanina vs. Russia stated that the victim's participation in the proceedings was based on the fact that the principles of equality and adversarial proceedings required a 'fair balance between the parties' and that each of them should be given a reasonable opportunity to present their case in conditions that do not put him or her in a less favorable position compared to his or her opponent. ${ }^{32}$ The participation of the victim in court proceedings is a necessary condition for ensuring the balance of interests of the parties and ensuring the right of a person to judicial protection of their own interests.

The analysis of Art. 193 of the CPC allows us to conclude that the victim is not a participant in the proceedings at the stage of pre-trial investigation during the decision of the investigating judge to apply for a measure of restraint or change it, which seems to limit his rights and legitimate interests. Scholars of law have repeatedly stressed that the victim should be given the right to participate in the consideration of a request for a measure of restraint in order to strengthen his/her role as an independent participant in criminal proceedings. ${ }^{33}$

Therefore, we believe that in the situation under consideration, the possibility of victim's direct participation or participation by videoconference (with his/her consent) in the hearing should be regulated by law.

\subsection{Reasonable Time Limits for Consideration of Criminal Cases in a Pandemic}

The reasonableness of time limits as one of the components of the right to a fair trial is enshrined in Part 3 of Art. 5, part 1 of Art. 6 of the Convention, Part 3 of Art. 9, Part 2.c Art 14 of the International Covenant on Civil and Political Rights (hereinafter - ICCPR or Covenant) and, in particular, stipulates that justice should not be administered with a delay that could compromise its effectiveness and credibility.

31 Declaration of Basic Principles of Justice for Victims of Crime and Abuse of Power [1985] Resolution 40/34 Gen Assembly <https://www.ohchr.org/en/professionalinterest/pages/victimsofcrimeandabuseofpower.aspx> accessed 03 August 2020.

32 Batsanina v Russia (App no 8927/02) ECHR 26 May 262009 in: Precedents of the European Court of Human Rights in Russia (2009) No 9 p 356-363.

33 See: SV Davydenko, 'Features of the procedural position of the victim in the application of precautionary measures' (2015) 3 Law and society 194-201; VO Sichko, 'Obrannia, skasuvannia abo zamina zapobizhnoho zahodu u sudovomu provadzhenni' ['Choice, cancellation or change of a measure of restraint in court proceedings'] (Candidate of Law thesis, Yaroslav Mudryi National University of Law 2019) 104-107. 
It was in the CPC of 2012 where for the first time at the normative level, the reasonableness of time limits was enshrined as a general principle of criminal proceedings, which corresponds to its task under Art. 2. The reasonableness of time limits is to ensure a speedy investigation and trial, so that anyone who commits a criminal offense is prosecuted to the extent of their guilt, no innocent person has been charged or convicted, no person has been subjected to unreasonable procedural coercion and proper legal procedure was applied to each participant in the criminal proceedings.

Given the practice of the ECHR and the provisions of parts 1, 4 of Art. 28 of the CPC, a reasonable time limit should be understood as the shortest period of consideration and resolution of criminal proceedings, procedural action or adoption of a procedural decision, which is sufficient to provide timely (without undue delay) judicial protection of violated rights, freedoms and interests and the tasks of criminal proceedings in general. ${ }^{34}$

One of the most important advantages of judicial activity, of course, is the availability of justice, its quality and efficiency which correlate with each other and complement each other. Modern law enforcement practice allows us to state that the efficiency of judicial proceedings is not covered exclusively by the organizational sphere. It should provide such a degree of access to justice that would promote the realization of one of the fundamental human rights, which is inextricably linked to the right to a fair trial, namely, participation in the trial without unjustified delay.

In paragraph 1 of Art. 6 of the Convention this right is formulated as the right to participate in a trial 'within a reasonable time'. A similar provision is formulated in paragraph 3 of Art. 14 of the ICCPR. As both the Covenant and the Convention apply concepts such as 'promptly, 'within a reasonable time', 'without undue delay', etc., the ECHR explains in sufficient detail the differences between them. The first concept is used in Art. 5 of the Convention and applies to detainees and arrested before being charged, who must be 'promptly' brought before a judge or other official exercising judicial power.

The notion of 'reasonable time', as well as 'without undue delay', refers to the length of the criminal proceedings and applies to the time that elapses from the moment the charge is brought until the end of the criminal proceedings.

The interpretation of the 'reasonable time' category depends on whether or not the accused is under arrest, as the arrested person has the right to have his or her case considered as a matter of priority and for the trial to proceed without delay. Therefore, the 'reasonable time' referred to in relation to the arrested person should be shorter than the 'reasonable time' referred to in relation to all accused (and not only the accused, if civil proceedings are also taken into account). In a number of decisions, the ECHR has formulated a legal position according to which a long delay in a trial can be acceptable, justified, due, for example, due to the complexity of the case, but this cannot justify a long detention. ${ }^{35}$

34 OV Kaplina, OG S Shylo (eds), Kryminalnyi process [Criminal proceedings] (a textbook) (Pravo 2018).

35 Trigiani $v$ Italy, ECHR 19 February $1991<\mathrm{http}: / /$ www.echr.coe.int $>$ accessed 03 August 2020; Manzoni $v$ Italy (App no 19218/91) ECHR 1 July $1997<$ http://www.echr.coe.int> accessed 03 August 2020; Calogero Diana $v$ Italy (App no 15211/89) ECHR 21 October $1996<$ http://www.echr.coe.int $>$ accessed 03 August 2020; Manieri v Italy (App 12053/86) ECHR <http://www.echr.coe.int> accessed 03 August 2020; Kalashnikov v Russia (App no 47095/99) ECHR 15 July $2002<$ https: //zakon.rada.gov.ua/laws/ show/980_057\#Text> accessed 03 August 2020. 
Determining in each case the presence of a violation of paragraph 1 of Art. 6 of the Convention or paragraph 3.c of Art. 14 of the Covenant, the ECHR considers the circumstances of the case, paying particular attention to its complexity, the actions of the parties and the authorities. Since the obligations under international treaties are assumed by states, only the delays caused by the latter can justify the conclusion that the requirements for a 'reasonable time' have not been met. The state should be able to guarantee a 'reasonable time' even in the event of disruption of public institutions in the country, for example, during a temporary political crisis or a coronavirus epidemic.

\subsection{Peculiarities of Judicial Control Proceedings in a Pandemic}

In this context, the problems of law enforcement practice that have arisen in connection with the introduction of amendments to the CPC of Ukraine have become especially relevant. It goes about the above-mentioned Law of Ukraine ${ }^{36}$ 'On Amendments to Paragraph 20-5 of Section XI 'Transitional Provisions' of the CPC of Ukraine on the peculiarities of judicial control over the rights, freedoms and interests of persons in criminal proceedings and consideration of certain issues during quarantine proceedings, established by the Cabinet of Ministers of Ukraine in order to prevent the spread of coronavirus disease (COVID-19)' of 13 April 2020 № 558-IX, which proposed a new version of paragraph 20-5 of chapter XI 'Transitional Provisions' of the CPC and standardized features of judicial control over the observance of the rights, freedoms and interests of persons in criminal proceedings and consideration of certain issues during court proceedings.

It should be noted that in the opinion of a Ukrainian legislator no special features of the procedure for the consideration of applications for permission to conduct covert investigative actions, as well as complaints about decisions, actions or inaction of the investigator or prosecutor during pre-trial investigation are required for the period of quarantine.

The first feature of the judicial control proceedings concerns the reduction of the time limit for considering a petition of a local court to transfer a petition to be considered by an investigating judge to another court within the jurisdiction of one appellate court or to another court within the jurisdiction of different appellate courts. This applies to cases, when a judge in the relevant court cannot be appointed (except for the Supreme Anti-Corruption Court). Such a request must be considered immediately, but not later than 24 hours from the date of its filing, by the chairman of the relevant appellate court (chairman of the Supreme Court of Cassation in case of transfer between courts within the jurisdiction of different appellate courts). ${ }^{37}$

In this case, it is considered that the date of receipt of such materials in court should be not the date of their transfer to the relevant chairman of the court, but the date and

36 The Law of Ukraine 'On Amendments to Paragraph 20-5 of Section XI 'Transitional Provisions' of the Criminal Procedure Code of Ukraine on the peculiarities of judicial control over the rights, freedoms and interests of persons in criminal proceedings and consideration of certain issues during court proceedings for the period of quarantine The Cabinet of Ministers of Ukraine in order to prevent the spread of coronavirus disease (COVID-19)' [2020] Bulletin of the Verkhovna Rada of Ukraine 19 Art 129.

37 Note that Part 3 of Art. 34 of the CPC of Ukraine, which provides for the general procedure for consideration of the relevant application, sets a five-day period. 
time of submission of the document specified in the registration mark (court stamp) affixed in accordance with paragraph $9 .{ }^{38}$ It is obligatory to indicate the time of receipt of the submission due to the shortened period (not more than 24 hours) for resolving the issue of changing the jurisdiction.

The second feature of the judicial control proceedings is related to the impossibility for a judge (panel of judges) to consider a request for election or extension of a preventive measure in the form of detention, except for a petition submitted to the High AntiCorruption Court.

In this case, it may be (1) transferred for consideration to another judge, determined in the manner prescribed by Part 3 of Art. 35 of the CPC, or (2) considered by the presiding judge, or in his absence - by another judge of the panel of judges, if the case is considered collectively, or (3) transferred to another court within the jurisdiction of one court of appeal or to a court within the jurisdiction of various courts of appeal in the manner prescribed by para. $6 \mathrm{pp}$. 20-5. The established multivariate solution to the situation that may arise indicates that this rule is not mandatory and provides discretionary powers to the court.

The question of transfer on the basis of para 5, point 20.5, of a request to choose or extend a measure of restraint in the form of detention for consideration to another court shall be decided by the chairman of the relevant appellate court (chairman of the Supreme Court of Cassation in case of transfer between courts within the jurisdiction of different appellate courts). The decision is made upon submission by a local court (court of appellate instance) immediately, but not later than 24 hours from the date of receipt of such submission, on which the relevant decision is made. Jurisdictional disputes between courts are not allowed in this case.

Analyzing the criminal procedural mechanisms mentioned above, we can state that they, in general, will promote the observance of reasonable time limits of criminal proceedings. They will also prevent situations when courts will not have control over the observance of the rights, freedoms and interests of persons in a criminal proceeding in a timely and a fair manner. The same applies to certain urgent issues consideration during pre-trial and court proceedings properly and within the statutory period.

At the same time, there are questions about the approach of the legislator, who, while formulating the normative structure, resorts to the use of evaluative concepts, in particular, 'in case of the impossibility to appoint an investigating judge in the relevant court, 'in case of the impossibility to consider a request for election or extension of a preventive measure in the form of detention... it may be transferred. Thus, courts are given wide discretion regarding the interpretation of the above provisions, because it is not established exactly which cases are in question. This, in turn, may lead to a violation

38 T Slutska, 'Zminy do KPK na period dii karantynu: analiz Zakonu, opublikovanoho 22 kvitnia 2020 roku' ['Amendments to the CPC for the period of quarantine: analysis of the Law published on 22 April 2020'] <https://protocol.ua/ru/zmini_do_kpk_na_period_dii_karantinu_analiz_zakonu_opublikovanogo_22_kvitnya_2020_roku/> accessed 03 August 2020.

See also Instructions on record keeping in local and appellate courts, approved by the order of the State Judicial Administration of Ukraine of 20 August 2019 № 814 and item 2.12. Instructions on record keeping of the Supreme Court, approved by the order of the Chief of Staff of the Supreme Court of 31 January 2020 № 11. 
of the rights, freedoms and interests of the defense, as well as of the provisions of Art. 6 of the Convention.

In addition, legal clarity is not provided by the provisions of para 10 , point 20.5 , chapter $\mathrm{XI}$ of the CPC of Ukraine, which stipulate that during the pre-trial investigation and during the trial, a request for extension of detention shall be submitted no later than ten days before the expiration of the previous detention order. The increase in the application period from 5 to 10 days is explained by the need to ensure compliance with the detention period specified in the previous decision, as due to quarantine measures, timely court hearings may be difficult. At the same time, the problem of noncompliance with the 10 -week time limit by the prosecution remains unresolved. It is believed that the only legal consequence of such a violation should be the release of a person from custody. In fairness, we note that the provisions of Chapter 18 'Precautions, Detention' the problem is raised, while unfortunately, it is not resolved. This should be considered as a significant gap in current procedural law, as it causes a violation of the right of the protection of suspects, the accused and the defense counsel. Incidentally, we should recall that the right to have the time and opportunities necessary to prepare their defense is provided for in paragraph 3.b of Art. 6 of the Convention

It is noteworthy that under the conditions of the quarantine, the defense 'received' an additional argument in the motivation of the request to change the pre-trial detention measure to a milder one, namely the threat of COVID-19 in the pre-trial detention centre.

As an example, the panel of judges of the Horodyshche District Court of Cherkasy Oblast considered the claim of their accused defense counsel to change the measure of restraint in the form of detention to a milder measure of restraint due to the fact that, among other things, '...the accused under conditions of isolation was not provided with a mask or gloves; there is a risk of disease; and evidence that the mother is elderly, disabled, in need of care, which is necessary at this time, when the state declared a coronavirus pandemic, and who is at risk.... However, in the court's view, these arguments were not sufficient to satisfy the request, and the detention period was extended. ${ }^{39}$

The case law of the ECHR provides some guidance on understanding the possibility and appropriateness of releasing persons from custody due to the risk of infection. Jeremy McBride in his article 'An Analysis of COVID-19 Responses and ECHR Requirements' notes:

'The conditional release of persons from prison - as is envisaged in the derogations of Georgia and Latvia - could protect those released from the risk of being infected. However, this should not occur without assessing the consequent risk to members of the public that this might pose as the infliction of physical violence by a released person could be in breach of the duty of care to the victim, entailing a violation of Art.s 2 and 3 (see, e.g., Maiorano and Others v. Italy, no. 28634/06, 15 December 2009 and Opuz v. Turkey, no. 33401/02, 9 June 2009). The Latvian derogation also seems to envisage the possible prolongation of prisoners' sentences. Any such prolongation would, given the

39 Case № 704/16/16-k (Horodyshche District Court of Cherkasy Region, 30 March 2020) <http://reyestr. court.gov.ua/Review/88555565> accessed 03 August 2020. 
likely absence of a causal connection with the original sentence, not be justified under Art. 5(1) (a). Furthermore, in the absence of a being a measure required to prevent the spread of infectious diseases - such as where the prisoner concerned has become infected with COVID-19 - and thus a justifiable ground for deprivation of liberty pursuant to Art. 5(1)(d), reliance on the derogation would undoubtedly be necessary to prevent any violation of the Convention. However, in such circumstances, it is hard to see delayed release really being strictly required by the exigencies of the situation. ${ }^{30}$

Analysis of paragraph 7 item 20-5 chapter XI of the CPC of Ukraine shows that the practical implementation of its normative content may lead to a violation of the deadlines established by the general provisions of the CPC for the consideration of certain issues within the competence of the investigating judge or court. Thus, there is a provision, according to which the consideration of issues under the powers of an investigating judge or court (except for consideration of a request to choose a measure of restraint in the form of detention) by its decision, taken on its own initiative or at the request of a party to criminal proceedings, can be conducted by videoconferencing, of which the parties of the criminal proceedings are notified in the manner prescribed by law. However, this provision does not take into account, that, in accordance with Part 8 of Art. 135 of the CPC, a person must receive a summons or be notified by other means no later than 3 days before the day when he is obliged to arrive on summons.

At the same time, according to the criminal procedure legislation of Ukraine, the petition of the investigator or prosecutor to impose a fine on the person, temporary restriction on the use of a special right, removal of a person from office, seizure of property, precautionary measure should be considered by the investigating judge not later than three days from the date of its receipt in court during the pre-trial investigation. The timeframe for the request for seizure of property is even less - not later than two days.

Such conflict, in any case, may lead to a violation of the rights and legitimate interests of the participants in the criminal proceedings and will not help to ensure compliance with reasonable time limits.

\section{CONCLUSIONS}

It is obvious that during a pandemic the introduction of certain restrictions is a necessary measure to preserve the health and life of the population, but at the same time, emergency measures must be based on the principles of rule of law, legality, legal certainty and proportionality, and be sufficient in case of danger, as well as be accompanied by a number of guarantees against the arbitrariness of the authorities.

Ukraine has not declared a derogation from the Convention, therefore, the antiepidemiological measures introduced in criminal proceedings should be based on the inadmissibility of restrictions on fundamental human rights guaranteed by the Convention. The vast majority of the changes introduced by the Ukrainian legislature

$40 \quad$ Jeremy McBride, 'An Analysis of COVID-19 Responses and ECHR Requirements' ECHR BLOG $<$ http://echrblog.blogspot.com/2020/03/an-analysis-of-covid-19-responses-and.html > accessed 03 August 2020. 
were established by law, pursued a legitimate aim, were proportionate and necessary in a democratic society.

Changes aimed at restricting the access of persons who are not participants in the trial to a court hearing during quarantine do not violate the fundamental rights of persons and are not aimed at terminating the principle of publicity of criminal proceedings. Due to the current situation, the legislator proposed only certain restrictions containing a set of guarantees against the abuse of rights, which are related to the discretion of the court decision, timeliness, selectivity and clear purpose.

The evaluative concept 'the threat to the life or health of a person' determines the purpose of the introduced restrictions related to the publicity of criminal proceedings. When interpreting this concept, the reasoning should be based on the fact that the protection of life and health is a legitimate goal. It determines the possibility of restrictions due to the fact that the investigating judge may assume, that there is a threat to the life and health of the court and the participants in the proceedings, which arise from internal conviction on the base of the general situation in the territory, area or place.

Given the importance of restricting the constitutional human right to liberty and security of person, the authors believe that the amendments to the CPC of Ukraine should be subject to revisions, according to which the extension of detention may take place by videoconference, as such an approach without a system of guarantees of voluntary consent of the suspect or accused is capable of leading to a quasi-automatic continuation of this most severe precautionary measure.

Also, despite the general positive direction of the amendments to the CPC of Ukraine for the period of quarantine established by the Cabinet of Ministers of Ukraine to prevent the spread of coronavirus (COVID-19), at present there is a need to talk about creating an effective mechanism for judicial control over rights, freedoms and legitimate interests of persons in criminal proceedings, as well as the creation of a system of guarantees of reasonable terms of criminal proceedings in a pandemic. 